\title{
EFEKTIFITAS PERUBAHAN UU NO 16 TAHUN 2019 TENTANG PERUBAHANATAS UU NO 1 TAHUN 1974 TENTANG PERKAWINAN TERHADAP PENETAPAN DISPENSASI KAWIN (Studi Kasus Di Pengadilan Agama Majalengka Kelas IA)
}

\author{
Rani Dewi Kurniawati ${ }^{1}$
}

\begin{abstract}
ABSTRAK
Perkawinan merupakan peristiwa penting bagi kehidupan manusia, bahkan menjadi kebutuhan dasar bagi setiap manusia. Perkawinan tidak hanya dilakukan oleh orang dewasa, tetapi juga dilakukan oleh remaja yang belum memenuhi syarat umur dalam Undang-undang Perkawinan dengan mendapatkan Dispensasi Kawin dari Pengadilan. Pasal 7 ayat (1) Undangundang Nomor 1 Tahun 1974 tentang Perkawinan menyebutkan "Perkawinan hanya diizinkan jika pihak pria sudah mencapai umur 19 tahun dan wanita 16 tahun." Namun ketentuan tersebut sudah diamandemen oleh Undang-undang Nomor 16 Tahun 2019 yang mana disebutkan "Perkawinan hanya diizinkan apabila pria dan wanita sudah mencapai umur 19 tahun." Seiring dengan hal tersebut, penulis mengadakan penelitian yang bertujuan untuk mengetahui, mengkaji, dan menganalisis faktor penyebab diajukannya permohonan dispensasi kawin, pertimbangan yang digunakan hakim dalam menangani permohonan dispensasi kawin, dan efektifitas Amandemen Undang-undang Perkawinan terhadap permohonan dispensasi kawin yang masuk di Pengadilan Agama Majalengka. Dengan menggunakan kerangka pikir Teori Negara Hukum, Teori Kepastian Hukum dan Teori Perkawinan.

Metode penelitian yang digunakan adalah deskriptif analisis, dengan menggunakan pendekatan dan analisis data yuridis kualitatif. Yaitu pemaparan data yang diperoleh dan menggambarkan peraturan perundang-undangan yang berlaku dikaitkan dengan teori hukum dan praktek yang menyangkut permasalahan secara sistematis, lengkap dan logis kemudian dianalisis dan menghasilkan kesimpulan.

Berdasarkan penelitian yang telah dilakukan, maka ditemukan beberapa faktor yang melatarbelakangi permohonan Dispensasi Kawin adalah 1. Faktor pencegahan, sebab orangtua khawatir jika anaknya melakukan hal yang dilarang oleh agama karena melihat anaknya berhubungan sudah sangat lama dan dekat. 2. Faktor pengobatan, dimaksudkan karena keluarga dan pasangan menjadi bahan gunjingan dan dikucilkan karena hamil diluar nikah, serta ditakutkan anak tersebut tidak memiliki kedudukan dimata hukum. 3. Ekonomi rendah menjadikan orangtua menganggap dengan menikahkan anaknya maka beban perekonomian keluarga akan berkurang. Dasar pertimbangan yang digunakan hakim dalam menetapkan dispensasi kawin adalah sesuai aturan formil serta keadilan dan kesejahteraan masyarakat demi tercapainya
\end{abstract}

\footnotetext{
${ }^{1}$ Dosen FH Universitas Majalengka, Email : rani.dewikurniawati@gmail.com
} 
kemaslahatan dan mengurangi kemudharatan. Kenaikan usia minimum perkawinan bagi anak perempuan merupakan salah satu penyebab terjadi kelonjakan permohonan dispensasi kawin di Pengadilan Agama Majalengka. Dalam periode 6 bulan setelah Amandemen Undang-undang Perkawinan, memperlihatkan kenaikan yang signifikan dan mengakibatkan terjadinya penumpukan permohonan di Pengadilan Agama Majalengka,sehingga dengan demikian dapat disimpulkan tidak efektif.Saran yang dapat diberikan oleh penulis, hendaknya orang tua memberikan pengawasan terhadap anaknya lebih ketat, terlebih ketika anak tersebut sudah mempunyai pasangan namun belum terjadi pernikahan. Dalam persidangan hakim diharapkan lebih selektif lagi, mengingat akibat dari perkawinan dibawah umur sangat menghawatirkan. Kenaikan usia perkawinan sebaiknya diuji lagi kelayakannya, karena hal tersebut berakibat kepada penumpukan permohonan dispensasi kawin yang terjadi di Pengadilan.

Kata Kunci: Perkawinan, Dispensasi, Amandemen. 
PRESUMPTION of LAW

Fakultas Hukum Universitas Majalengka

\section{A. Latar Belakang}

Manusia merupakan makhluk sosial yang mana satu dan yang lainnya saling berinteraksi dan membutuhkan. Manusia diciptakan dalam jenis laki-laki dan perempuan serta mempunyai fitrah untuk hidup bahagia dan berpasang pasangan dalam menjalankan kehidupannya, sehingga manusia melakukan perkawinan untuk mendapat pendamping hidup dan melanjutkan keturunan.

Perkawinan adalah perjanjian suci untuk membentuk keluarga antara seorang laki-laki dengan seorang perempuan. ${ }^{2}$ Ikatan suami istri yang didasarkan niat suci ini diharapkan tumbuh berkembang menjadi keluarga/rumah tangga bahagia dan kekal berdasarkan Ketuhanan Yang Maha Esa. Perkawinan sangat penting bagi kehidupan manusia, bahkan menjadi kebutuhan dasar bagi setiap manusia normal dan merupakan awal dari terbentuknya institusi kecil dalam keluarga. Dalam kehidupan bermasyarakat, ditemui suatu penilaian yang umum, ialah bahwa orang yang berkeluarga mempunyai kedudukan yang lebih dihargai dari mereka yang tidak kawin. ${ }^{3}$

Dalam lingkungan keluarga ini pula seorang anak manusia dilahirkan, dibesarkan, dididik, dan diarahkan agar kelak kemudian hari menjadi manusia dan anggota masyarakat yang beriman, bertakwa, berilmu pengetahuan, berteknologi, dan berwawasan nusantara. ${ }^{4}$ Untuk itu suami istri harus saling membantu dan melengkapi, agar masing-masing dapat mengembangkan kepribadiannya membantu dan mencapai kesejahteraan spiritual dan materil. ${ }^{5}$

Perjalanan kehidupan suami istri dalam menjalankan kehidupan rumah tangga memang sangat dinamis, tak satupun keluarga yang hidup berjalan dengan mulus sesuai keinginan tanpa adanya gelombang problematika yang senantiasa berubah. Kemampuan sebuah keluarga dalam menghadapi persoalan rumah tangga salah satunya dengan kematangan suami istri. ${ }^{6}$ Kematangan tersebut bisa terlihat dari kecukupan umur dan persiapan lahir dan batin dari kedua belah pihak mempelai, Karena usia merupakan salah satu hal yang berpengaruh bagi mental dan rasa tanggungjawab kedua calon pasangan.

Perkawinan dibawah umur atau perkawinan dini merupakan istilah yang tidak asing lagi. Perkawinan dini masih dilakukan oleh para orang tua, khususnya di beberapa kawasan Nusantara akibat pengaruh adat kebiasaan setempat. Anak-anak yang belum matang jiwa raganya, dijodohkan oleh orang

${ }^{2}$ Mardani, Hukum Keluarga Islam di Indonesia, Edisi Pertama, Prenadamedia Group, Jakarta, 2016, hlm. 24.

${ }^{3}$ Ibid, hlm. 25.

4 Moh. Zahid, Dua Puluh Lima Tahun Pelaksanaan Undang-undang Perkawinan, Departemen Agama R.I., Jakarta, 2002, hlm. 1. Lihat Nurwafa Ramadanti, Aspek-Aspek Hukum Terhadap Dampak Perkawinan Yang Tidak Tercatat Dalam Perspektif Hukum Positif Dan Hukum Islam, Skripsi Fakultas Hukum Universitas Majalengka, 2020, hlm 2.

${ }^{5}$ Mardani, Op.Cit hlm. 27.

6 Andi Syamsu Alam, Usia Ideal Memenuhi dunia Perkawinan, Kencana Mas Publishing House, Jakarta, 2005 hlm. 16-17. Lihat Ummu Kalsum, Pengaruh Dispensasi Nikah Terhadap Tingkat Perceraian Di Pengadilan Agama Watampone Kelas IA, Skripsi, hlm.

2. http://repositori.uin-alauddin.ac.id/2991/ diakses pada tanggal 20 maret 2020. 
PRESUMPTION of LAW

Fakultas Hukum Universitas Majalengka

Volume 3 Nomor 2 Oktober 2021

tua, tanpa mereka itu tahu arti dan makna perkawinan yang dilakoninya. ${ }^{7}$ Perkawinan dibawah umur ini dilakukan oleh anak yang ada pada masa peralihan antara masa anak-anak dan masa dewasa dimana anak-anak mengalami perubahan cepat disegala bidang. Mereka bukan lagi anak-anak, baik bentuk badan, sikap dan cara berpikir dan bertindak, tetapi bukanlah orang dewasa yang telah matang. ${ }^{8}$

Undang-undang Perkawinan telah mengatur batasan minimal umur untuk melangsungkan perkawinan. Yaitu dalam Pasal 7 ayat (1) Undang-undang Nomor 1 Tahun 1974 tentang Perkawinan disebutkan bahwa "perkawinan hanya diizinkan jika pihak pria sudah mencapai umur 19 (sembilan belas)) tahun dan pihak wanita sudah mencapai umur 16 (enam belas) tahun. Namun ketentuan umur tersebut telah di rubah melalui Amandemen Undang-undang Nomor 1 Tahun 1974 tentang Perkawinan menjadi Undang-undang Nomor 16 Tahun 2019 tentang Perubahan Atas Undang-undang Nomor 1 Tahun 1974 yang mana disebutkan "perkawinan hanya diizinkan apabila pria dan wanita sudah mencapai umur 19 (sembilan belas) tahun.

Batasan umur tersebut bertujuan agar membatasi pernikahan anak dibawah umur agar pemuda pemudi yang akan menikah sudah matang jiwa raganya dalam membentuk keluarga atau rumah tangga yang bahagia dan kekal. Begitu pula dimaksudkan untuk mencegah marak tingginya laju kelahiran dan agar pasangan suami istri mendapatkan keturunan yang baik dan sehat serta meminimalisir terjadinya kematian ibu dan anak.

Meskipun telah menetapkan batasan usia perkawinan sedemikian rupa di dalam peraturan perundang-undangan, tidak menutup kemungkinan seorang melangsungkan perkawinan dibawah umur. Perkawinan bagi anak dibawah umur minimum bisa dilangsungkan dengan penetapan pengadilan, orang tua pihak pria dan/atau pihak wanita dapat meminta dispensasi kepada pengadilan dengan alasan sangat mendesak disertai bukti-bukti pendukung yang cukup.

Berbagai macam alasan permohonan dispensasi kawin diajukan oleh para pihak yang berkepentingan. Di antaranya adalah anak yang akan melangsungkan perawinan menyatakan kehendak untuk berumah tangga dengan segala konsekuensinya atau telah siap lahir batin, merasa tidak melanggar hukum agama karena telah akil baligh, telah dilamar atau tunangan dan khawatir kalau terjerumus perbuatan yang dilarang agama, orang tua siap mendukung moril dan material dan lain sebagainya. ${ }^{9}$ hal tersebut menjadi penyebab tingginya tingkat permohonan dispensasi kawin di pengadilan.

Berdasarkan apa yang telah diuraikan tersebut diatas, maka penulis tertarik untuk melakukan penelitian dengan judul "EFEKTIFITAS PERUBAHAN UU NO 16 TAHUN 2019 TENTANG PERUBAHAN ATAS

\footnotetext{
${ }^{7}$ Moch. Isnaeni, Hukum Perkawinan Indonesia, Refika Aditama, Bandung, 2016, hlm. 87.

8 Sabariah, Perkembangan Fisik Remaja, jurnal, diakses dari http://ejournal.uinsuka.ac.id/pusat/ aplikasia/article/viewFile/1362/1180 pada 20 maret 2020.

${ }^{9}$ Sri Rahmawaty Yunus dan Ahmad Faisal, "Analisis Penetapan Dispensasi Kawin Dalam Perspektif Undang-Undang Perlindungan Anak (Studi Kasus Di Pengadilan Agama Limboto” Jurnal Ilmiah Al-Jauhari (JIAJ), 2 September 2018, hlm. 88.
} 


\section{UU NO 1 TAHUN 1974 TENTANG PERKAWINAN TERHADAP PENETAPAN DISPENSASI KAWIN".}

\section{B. Identifikasi Masalah}

Berdasarkan permasalahan yang dikemukakan dalam latar belakang diatas sifatnya masih umum, untuk itu penulis merasa perlu membatasi masalah dengan jelas, agar dalam penelitian tidak terjadi kesimpangsiuran yang akan berakibat mengaburkan tujuan yang hendak dicapai dalam penelitian ini. Untuk itu penulis hanya memfokuskan pada penelitian ini terhadap:

1. Faktor apa yang melatarbelakangi diajukannya Permohonan Dispensasi Kawin?

2. Bagaimana Pertimbangan Hakim Pengadilan Agama Majalengka dalam menangani Permohonan Dispensasi Kawin?

3. Bagaimana efektifitas Amandemen Undang-undang Perkawinan terhadap Permohonan Dispensasi Kawin?

\section{Tujuan Penelitian}

Adapun tujuan dalam hal penelitian ini yaitu untuk menambah wawasan pengetahuan dan pemahaman penulis akan arti pentingnya ilmu hukum dalam teori dan praktik menganalisis masalah hukum. Berdasarkan identifikasi masalah di atas, maka tujuan penelitian ini ditetapkan sebagai berikut :

1. Untuk mengetahui, mengkaji dan menganalisis faktor yang melatarbelakangi diajukannya permohonan Dispensasi Kawin.

2. Untuk mengetahui, mengkaji dan menganalisis Pertimbangan Hakim Pengadilan Agama Majalengka dalam menangani Permohonan Dispensasi Kawin.

3. Untuk mengetahui mengkaji dan menganalisis efektifitas Amandemen Undang-undang Perkawinan terhadap Permohonan Dispensasi Kawin di Pengadilan Agama Majalengka.

\section{Kerangka Pemikiran}

Kerangka pemikiran adalah landasan penelitian, sebagai pijakan peneliti agar penelitian menjadi kokoh dan memiliki landasan yang kuat sehingga penelitian tersebut dapat diandalkan. ${ }^{10}$

Sehubungan dengan permasalahan yang telah diuraikan diatas, maka penulis memuat beberapa teori untuk memperkuat peneliti dan sebagai pijakan penelitian, sebagai berikut yaitu :

1. Teori Negara Hukum

Negara Indonesia adalah Negara Hukum. ${ }^{11}$ Artinya Negara Hukum adalah Negara yang berdiri diatas hukum yang menjamin keadilan kepada warga negaranya. Keadilan merupakan syarat bagi terciptanya kebahagiaan

10 Fakultas Hukum Universitas Majalengka, Panduan Skripsi, Fakultas Hukum Universitas Majalengka, Majalengka, 2019, hlm. 16.

${ }^{11}$ Pasal 1 ayat (3) Undang-undang Dasar Negara Republik Indonesia Tahun 1945. 
PRESUMPTION of LAW Fakultas Hukum Universitas Majalengka

Volume 3 Nomor 2 Oktober 2021

hidup untuk warga negaranya, dan sebagai dasar dari pada keadilan itu perlu diajarkan rasa susila kepada setiap manusia agar ia menjadi warga Negara yang baik. Demikian pula peraturan hukum yang sebenarnya hanya ada jika peraturan hukum itu mencerminkan keadilan bagi pergaulan hidup antar warga negaranya. ${ }^{12}$ Segala tingkah laku warga negaranya harus sesuai dengan hukum yang berlaku atau hukum positif atau aturan-aturan lainnya seperti tidak bertentangan dengan undang-undang, norma-norma, kaidahkaidah, asas-asas dan lain-lain.

Prinsip penting dalam negara hukum adalah perlindungan yang sama (equal protection) atau persamaan dalam hukum (equality before the law). Perbedaan perlakuan hukum hanya boleh jika ada alasan yang khusus, misalnya, anak-anak yang di bawah umur 17 tahun mempunyai hak yang berbeda dengan anak-anak yang di atas 17 tahun. Perbedaan ini ada alasan yang rasional. Tetapi perbedaan perlakuan tidak dibolehkan jika tanpa alasan yang logis, misalnya karena perbedaan warna kulit, gender agama dan kepercayaan, sekte tertentu dalam agama, atau perbedaan status seperti antara tuan tanah dan petani miskin. Meskipun demikian, perbedaan perlakuan tanpa alasan yang logis seperti ini sampai saat ini masih banyak terjadi di berbagai negara, termasuk di negara yang hukumnya sudah maju sekalipun.

2. Teori kepastian Hukum

Negara hukum mensyaratkan bahwa setiap tindakan dari negara haruslah bertujuan untuk menegakkan kepastian hukum, dilakukan secara setara, menjadi unsur yang mengesahkan demokrasi, dan memenuhi tuntutan akal budi. ${ }^{13}$ Menurut Kelsen, hukum adalah sebuah sistem norma. Norma adalah pernyataan yang menekankan aspek "seharusnya" atau das sollen, dengan menyertakan beberapa peraturan tentang apa yang harus dilakukan. Norma-norma adalah produk dan aksi manusia yang deliberatif. Undang-Undang yang berisi aturan-aturan yang bersifat umum menjadi pedoman bagi individu bertingkah laku dalam bermasyarakat, baik dalam hubungan dengan sesama individu maupun dalam hubungannya dengan masyarakat. Aturan-aturan itu menjadi batasan bagi masyarakat dalam membebani atau melakukan tindakan terhadap individu. Adanya aturan itu dan pelaksanaan aturan tersebut menimbulkan kepastian hukum. ${ }^{14}$

Menurut Utrecht, kepastian hukum mengandung dua pengertian, yaitu pertama, adanya aturan yang bersifat umum membuat individu mengetahui perbuatan apa yang boleh atau tidak boleh dilakukan, dan kedua, berupa

${ }^{12}$ Moh. Kusnardi dan Harmaily, Hukum Tata Negara Indonesia, Sinar Bakti, Jakarta, 1988, hlm. 163. Lihat M. Sulaeman Jajuli, Kepastian Hukum Gadai Tanah Dalam Islam, CV. Budi Utama, Yogyakarta, 2015, hlm. 26. Diakses dari https://books.google.co.id, pada 20 maret 2020.

13 Diakses dari https://id.wikipedia.org/wiki/Negara_hukum\#: :text=Negara\%20huk um\%20(bahasa\%20Belanda\%3A\%20rechtsstaat,Inggris\%20(Anglo\%2DSaxon). Pada tanggal 21 maret 2020.

14 Peter Mahmud Marzuki, Pengantar Ilmu Hukum, Kencana, Jakarta, 2008, hlm.58. Lihat Bab II hlm. 34. Diakses dari http://repository.unpas.ac.id/33652/1/07\%20BAB\%20II.pdf, pada 21 maret 2020 . 
PRESUMPTION of LAW

Fakultas Hukum Universitas Majalengka

Volume 3 Nomor 2 Oktober 2021

keamanan hukum bagi individu dari kesewenangan pemerintah karena dengan adanya aturan yang bersifat umum itu individu dapat mengetahui siapa saja yang boleh dibebankan atau dilakukan oleh negara terhadap individu. ${ }^{15}$

Ajaran kepastian hukum ini berasal dari ajaran Yuridis-Dogmatik yang didasarkan pada aliran pemikiran positivistis di dunia hukum, yang cenderung melihat hukum sebagai sesuatu yang otonom, yang mandiri, karena bagi penganut pemikiran ini, hukum tak lain hanya kumpulan aturan. Bagi penganut aliran ini, tujuan hukum tidak lain dari sekedar menjamin terwujudnya kepastian hukum. Kepastian hukum itu diwujudkan oleh hukum dengan sifatnya yang hanya membuat suatu aturan hukum yang bersifat umum. Sifat umum dari aturan-aturan hukum membuktikan bahwa hukum tidak bertujuan untuk mewujudkan keadilan atau kemanfaatan, melainkan semata-mata untuk kepastian. ${ }^{16}$

3. Teori perkawinan

Beberapa asas perkawinan yang telah diatur dalam Undang-undang Nomor 16 Tahun 2019 dan Undang-undang Nomor 1 Tahun 1974 diantaranya adalah ketentuan pasal 7 dimana perkawinan hanya diizinkan apabila pria dan wanita sudah mencapai umur 19 (Sembilan belas) tahun. Ketentuan tersebut dimaksudkan untuk tercapainya suatu tujuan pernikahan agar kehidupan rumah tangga yang bahagia, kekal, dan abadi. Namun ketentuan tersebut dikecualikan oleh ayat 2 (dua) dimana dalam hal terjadinya penyimpangan terhadap ketentuan umur sebagaimana dimaksud pada ayat (1), orang tua pihak pria dan/atau orang tua pihak wanita dapat meminta dispensasi nikah kepada pengadilan dengan alasan sangat mendesak disertai bukti-bukti pendukung yang cukup.

\section{E. Metode Penelitian}

1. Spesifikasi Penelitian

Spesifikasi penelitian yang digunakan adalah deskriktif analisis yaitu menganalisa objek penelitian dengan memaparkan situasi dan keadaan, dengan cara pemaparan data yang diperoleh sebagaimana adanya yang menggambarkan peraturan perundang-undangan yang berlaku dikaitkan dengan teori hukum dan praktek pelaksanaan yang menyangkut permasalahan dalam uraian diatas secara sistematis, lengkap dan logis. kemudian dianalisis yang menghasilkan beberapa kesimpulan. ${ }^{17}$

2. Metode Pendekatan

Penelitian ini menggunakan metode pendekatan yuridis normatif yaitu suatu penelitian yang membahas tentang asas-asas hukum didasarkan pada

${ }^{15} \mathrm{Ibid}$, hlm. 35.

${ }^{16}$ Achmad Ali, Menguak Tabir Hukum (Suatu Kajian Filosofis dan Sosiologis), Toko Gunung Agung, Jakarta, 2002, hlm.82-83. Lihat Bab II hlm. 17. Diakses dari http://repository.uma.ac.id /bitstream/123456789/1435/5/138400056_File5.pdf, pada 21 Maret 2020.

${ }^{17}$ Lihat pdf Bab I hlm. 18, diakses dari http://repository.unpas.ac.id/41852/4/F.\%20BA B\%201.pdf, pada tanggal 22 maret 2020. 
Peraturan Perundang-undangan yang berlaku dengan mengutamakan bahan kepustakaan dan implementasianya dalam praktik. Untuk itu diperlukan penelitian yang merupakan suatu rencana pokok dalam pengembangan ilmu pengetahuan. Menurut Soerjono Soekanto pendekatan yuridis normatif yaitu penelitian hukum yang dilakukan dengan cara meneliti bahan pustaka atau data sekunder sebagai bahan dasar untuk diteliti dengan cara mengadakan penelusuran terhadap peraturan-peraturan dan literatur-literatur yang berkaitan dengan permasalahan yang diteliti. ${ }^{18}$

3. Tahap Penelitian

Pada penelitian ini peneliti menggunakan beberapa tahap penelitian, yaitu :

a. Penelitian kepustakaan

Dalam penelitian ini, digunakan penelitian kepustakaan yang bersifat mengikat pada masalah-masalah yang diteliti, yang terdiri dari :

1) Bahan hukum primer, yaitu terdiri dari beberapa peraturan perundangundangan antara lain :

a) Undang-undang Dasar Republik Indonesia Tahun 1945.

b) Kitab Undang-undang Hukum Perdata.

c) Kitab Undang-undang Hukum Acara Perdata.

d) Undang-undang Nomor 1 Tahun 1974 Tentang Perkawinan.

e) Undang-undang Nomor 16 Tahun 2019 Atas Perubahan Undangundang Nomor 1 Tahun 1974 Tentang Perkawinan.

f) Peraturan Mahkamah Agung Nomor 5 Tahun 2019 Tentang Pedoman Mengadili Permohonan Dispensasi Kawin.

2) Bahan hukum sekunder, yaitu bahan-bahan yang erat kaitannya dengan bahan hukum primer, yaitu :

a) Hasil Karya Ilmiah Para Sarjana.

b) Hasil-Hasil Penelitian.

c) Doktrin Sarjana.

3) Bahan hukum tersier, yaitu bahan-bahan yang memberikan informasi tentang bahan hukum primer dan sekunder, yaitu :

a) Artikel Koran Dan Majalah.

b) Artikel Situs Internet.

b. Penelitian lapangan

Penelitian lapangan dimaksudkan untuk memperoleh informasi yang dibutuhkan untuk melengkapi data-data studi pustaka. Data yang diperoleh dari penelitian lapangan ini berupa data dari Pengadilan Agama Majalengka. Dalam penelitian lapangan ini juga digunakan metode tanya jawab antara peneliti dan narasumber di lapangan yang dimaksudkan agar memperoleh data penunjang yang dapat memperkuat data yang telah di dapat dari kajian Pustaka.

${ }^{18}$ Soerjono Soekanto \& Sri Mamudji, Penelitian Hukum Normatif (Suatu Tinjauan Singkat), Rajawali Pers, Jakarta, 2001, hlm. 13-14. Lihat hlm. 28. Diakses dari http://digilib.unila.ac.id/528/ 8/BAB\%203.pdf, pada 22 maret 2020. 
4. Teknik Pengumpulan Data

Teknik pengumpulan data yang dilakukan adalah dengan cara :

a. Studi Kepustakaan

Dilakukan terhadap data sekunder untuk mendapatkan landasan teoritis, beberapa pendapat-pendapat atau hasil tulisan-tulisan para ahli atau pihak-pihak lain yang berwenang dan juga untuk mendapatkan informasi baik dalam bentuk ketentuan formal maupun data melalui naskah resmi.

b. Observasi Langsung

Teknik ini dilakukan untuk mengumpulkan, meneliti dan mengolah data yang diperoleh dari lapangan dengan melakukan observasi secara langsung terhadap objek yang di teliti.

5. Analisis Data

Analisis data yang digunakan dalam penelitian ini adalah yuridis kualitatif yang bertitik tolak pada analisis yuridis sistematis. Yang didasarkan pada Undang-undang Nomor 16 Tahun 2019 Atas Perubahan Undang-undang Nomor 1 Tahun 1974 Tentang Perkawinan dan Peraturan Mahkamah Agung Nomor 5 Tahun 2019 Tentang Pedoman Mengadili Permohonan Dispensasi Kawin.

6. Lokasi Penelitian

Penelitian lapangan dilakukan di beberapa lokasi untuk memperoleh data yang diperlukan yang mempunyai korelasi dengan masalah yang dikaji oleh peneliti, antara lain :
a. Penelitian kepustakaan dilakukan di perpustakaan Universitas Majalengka
b. Penelitian kepustakaan dilakukan di perpustakaan Fakultas Hukum Universitas Majalengka.
c. Penelitian lapangan di Pengadilan Agama Majalengka kelas IA.

\section{F. HASIL PENELITIAN}

\section{Tinjauan Hukum Faktor Yang Melatarbelakangi Permohonan Dispensasi Kawin Di Pengadilan Agama Majalengka}

Berdasarkan penelitian yang telah penulis lakukan di Pengadilan Agama Majalengka, dari tahun 2017-2019 terdapat 350 perkara yang masuk ke register perkara, namun dari data tersebut terdapat 347 pemohon yang diterima dan 3 pemohon yang ditolak. Hal tersebut memperlihatkan dalam periode 3 tahunan terdapat 347 pasangan yang akan melangsungkan perkawinan dibawah umur,

Selama ini faktor pengajuan dispensasi kawin di Pengadilan Agama dikalsifikasikan menjadi 2 macam yaitu karena faktor preventif (pencegahan) dan kuratif (penyembuhan) ${ }^{19}$ dan diluar alasan tersebut juga orang tua calon pasangan suami isteri yang akan melangsungkan

19 Gushairi, Problematika Dispensasi Kawin Di Pengadilan Agama, diakses dari https://badilag.mahkamahagung.go.id/artikel/publikasi/artikel/problematika-dispensasi-kawindipen gadilan-agama-oleh-gushairi-s-h-i-mcl-4-12. 
PRESUMPTION of LAW

Fakultas Hukum Universitas Majalengka

Volume 3 Nomor 2 Oktober 2021

perkawinan di bawah umur juga mengajukan dengan karena untuk meringankan beban ekonomi keluarga dan Pendidikan rendah.

1. Preventif (usaha pencegahan)

Pada masa remaja, banyak remaja mengalami perubahan baik secara fisik maupun secara psikologis, sehingga mengakibatkan perubahan sikap dan tingkah laku, seperti mulai memperhatikan penampilan diri, mulai tertarik dengan lawan jenis, berusaha menarik perhatian dan muncul perasaan cinta, akan timbul dorongan seksual, yang kemudian beralasan untuk melakukan hal-hal yang dilarang oleh agama untuk melakukan hubungan intim walaupun tidak terikat perkawinan terlebih dahulu sehingga memicu melakukan hal-hal negatif yang tidak dibenarkan.

Upaya preventif adalah pencegahan dari perbuatan zina yang dilakukan anak-anaknya, seperti halnya tujuan perkawinan dalam islam adalah untuk menjaga diri dari perbuatan maksiat. Bagi pasangan remaja yang sudah teramat dekat menjalani hubungan dan sering bertemu akan menimbulkan nafsu satu dengan yang lainnya, dan ditambah pada saat ini perkembangan media sosial, gaya hidup dan pergaulan remaja sangat kompleks, sehingga mengakibatkan kecendrungan mereka untuk bergaul bebas lebih tinggi, maka menyegerakan pernikahan adalah upaya untuk mengatasi bahaya bagi para remaja dari pergaulan bebas.

Walaupun belum cukup umur sebagian besar orang tua pemohon dispensasi kawin kebanyakan mereka beralasan, takut anak-anak mereka berbuat zina atau hamil dulu sebelum nikah. Pasalnya, mereka pacaran sudah lama dan sulit dipisahkan. Mereka memilih menikahkan anaknya sebagai solusinya dan mengajukan permohonan dispensasi kawin di Pengadilan.

2. Kuratif (usaha atau upaya penyembuhan)

Berdasarkan pemaparan hasil wawancara dengan hakim Pengadilan Agama Majalengka yang menyatakan bahwa hamil di luar nikah adalah menjadi faktor yang dominan dalam dispensasi kawin di Pengadilan Agama Majalengka. Tuntutan kebutuhan biologis yang ada pada setiap orang adalah suatu hal yang tidak bisa diabaikan begitu saja, karena kebutuhan biologis atau nafsu syahwat merupakan naluri yang kuat diantara naluri-naluri lainnya. ${ }^{20}$ sehingga para remaja terjerumus melakukan hubungan biologis yang mengakibatkan kehamilan. Kehamilan seharusnya menjadi sebuah berita yang membahagiakan, jika hadir pada mereka pasangan suami istri yang sudah melangsungkan perkawinan dan hal tersebut merupakan kabar baik yang dirindukan dan dinanti-nanti oleh pasangan suami istri dengan kehadiran si buah hati atau malaikat kecil yang menjadi penyejuk dalam kesehariannya.

Namun hal tersebut akan berbeda jika menimpa mereka para remaja putri khususnya yang masih sekolah dan belum melangsungkan proses perkawinan terlebih dahulu. Bahkan kehamilan akan menjadi

${ }^{20}$ Bayu Wasono, Op.Cit., hlm. 47. 
PRESUMPTION of LAW

Fakultas Hukum Universitas Majalengka

Volume 3 Nomor 2 Oktober 2021

kabar buruk yang sangat ditakutkan dan tidak diinginkan, karena ancaman bagi masa depan anak yang dilahirkannya tidak mempunyai ayah dan akan berakibat kepada gunjingan dan cemoohan, bagi mereka yang belum melakukan perkawinan akan dikucilkan oleh lingkungan masyarakat karena hal tersebut tidak diterima oleh masyarakat golongan tertentu.

Usaha penyembuhan bagi orang tua kedua pasangan yang tidak ada pilihan lain selain memberi pilihan pada anak dengan menikah untuk menutup aib yang diderita dan menyelamatkan status anak, juga untuk menjaga dari fitnah akibat dari hubungan luar nikah.

3. Faktor Ekonomi dan Pendidikan Rendah

Kehidupan sosial bermasyarakat tidak bisa dipisahkan dengan kedudukan status ekonomi keluarga yang menentukan kesejahteraan hidup. Keluarga yang mempunyai ekonomi yang kurang menganggap bahwa anak merupakan salah satu penyebab beban tanggungan keluarga. Banyak orang tua tidak kuat untuk mengurus lagi dan membiayai kehidupan anak-anaknya sehingga mengakibatkan orang tua tersebut menikahkan anaknya meskipun anak tersebut masih dibawah umur perkawinan. Karena kebanyakan orang tua menganggap bahwa ketika anaknya menikah, maka beban yang ditanggungnya menjadi berkurang.

Pada satu masyarakat yang relatif maju tingkat ekonomi dan pendidikannya, usia 19 tahun tentu masih terlalu rendah. Hampir rata-rata orang yang berpendidikan tinggi memilih sendiri menikah di atas usia rata-rata. Tetapi, bagi orang yang tidak mampu menempuh pendidikan tinggi karena ketidakberuntungan secara talenta dan ekonomi, menunggu usia 19 tahun untuk menikah tentu merupakan penyiksaan dan dalam tataran tertentu dapat disebut sebagai pelanggaran Hak Asasi Manusia.

\section{Tinjauan Yuridis Pertimbangan Hakim Pengadilan Agama Majalengka Dalam Mengabulkan Permohonan Dispensasi Kawin}

Hakim sebagai pelaksana kehakiman mempunyai kemerdekaan dan otoritas dalam menjalankan tugasnya, dalam menjalankan tugasnya hakim tidak dipengaruhi oleh suatu instansi manapun karena hakim hanya tunduk kepada hukum dan keadilan disamping itu juga, dalam membuat putusan hakim harus mempertimbangkan segala temuan, yang mana temuan tersebut harus dipertimbangkan untuk selanjutnya dijadikan pertimbangan untuk menentukan hukum.

Berdasarkan hasil penelitian penulis pada Pengadilan Agama Majalengka mengenai Dispensasi Perkawinan, penulis dapat melakukan wawancara langsung dengan seorang hakim yang menangani kasus perkawinan di bawah umur yakni dengan bapak Dr. Drs. H. Amin Manshur, S.H. M. Hum. selaku Hakim Pengadilan Majalengka. Dalam wawancara tersebut penulis memperoleh keterangan mengenai pertimbangan Hakim Pengadilan Agama Majalengka dalam memberikan dispensasi perkawinan.

Hakim dalam mempertimbangkan hukum, pada umumnya hakim akan menggunakan syllogisme dengan merumuskan aturan perundang-undangan 
dan fakta di persidangan menjadi sebuah keputusan. Untuk sampai kepada keputusan yang benar maka peraturan-perundang-undangan dan fakta persidangan harus sesuai. Ketika salah satu rumusan salah, akan menghasilkan keputusan yang salah.

Adapun yang menjadi pertimbangan majelis hakim dalam memutuskan perkara dispensasi nikah adalah sesuai dengan hukum (legal standing, adanya larangan perkawinan atau tidak), diluar hukum (keadilan masyarakat) (alasan pemohon pengajuan dispensasi nikah dan kemaslahatan/kemudharatan).

1. Berdasarkan Hukum

Melakukan perkawinan haruslah sesuai prosedur yang telah ditetapkan Undang-undang Perkawinan, namun ketika perkawinan itu harus tetap dilaksanakan karena suatu alasan tertentu maka dapat dilakukan penyimpangan yaitu dengan dispensasi perkawinan. dispensasi perkawinan akan dikabulkan apabila sudah sesuai dengan perundangundangan yang berlaku, yaitu antara lain:

a. Pasal 7 Undang-undang Perkawinan

(1) Perkawinan hanya diizinkan apabila pria dan wanita sudah mencapai umur 19 (sembilan belas) tahun.

(2) Dalam hal terjadi penyimpangan terhadap ketentuan umur sebagaimana dimaksud pada ayat (1), orang tua pihak pria dan/atau orang tua pihak wanita dapat meminta dispensasi kepada Pengadilan dengan alasan sangat mendesak disertai bukti-bukti pendukung yang cukup

b. Syarat administrasi berdasarkan Peraturan Mahkamah Agung Nomor 5 Tahun 2019

1) Surat penolakan kawin dari kua setempat

2) Fotocopy buku nikah pemohon calon suami isteri dan atau surat keterangan dari desa bagi yang nikah dibawah tangan.

3) Fotocopy KTP/domisili orang tua calon suami isteri

4) Fotocopy Akta Kelahiran calon suami isteri

5) Fotocopy KTP/domisili calon pasangan suami isteri

6) Fotocopy kartu keluarga (KK) calon suami isteri

7) Fotocopy Ijazah pendidikan terakhir anak calon suami isteri

8) Surat keterangan penghasilan calon suami dari Desa setempat

9) Surat keterangan hamil dari Puskesmas/Bidan/Dokter jika calon isteri sudah hamil

10) Surat kematian orang tua calon suami/isteri jika orang tuanya sudah meninggal dunia dari Desa

11) Surat keterangan status calon suami isteri dari Desa setempat

12) Fotocopy Akta Cerai calon suami/isteri bagi yang sudah bercerai

13) Surat permohonan rangkap 7

14) Panjar Biaya

c. Tidak adanya larangan perkawinan

Alasan majelis mengabulkan permohonan dari pemohon adalah agar tidak terjadinya perbuatan yang dilarang oleh agama. Landasan 
PRESUMPTION of LAW

Fakultas Hukum Universitas Majalengka

hakim dalam mengabulkan permohonan dispensasi perkawinan adalah apabila tidak ada terdapat halangan perkawinan sesuai yang diatur dalam BAB VI pasal 39 sampai dengan pasal 44 Kompilasi Hukum Islam (KHI).

Pasal 39 : Dilarang melangsungkan perkawinan antara seorang pria dengan seorang wanita disebabkan:

(1) Karena pertalian nasab:

a) dengan seorang wanita yangmelahirkan atau yang menurunkannya atau keturunannya;

b) dengan seorang wanita keturunan ayah atau ibu;

c) dengan seorang wanita saudara yang melahirkannya

(2) Karena pertalian kerabat semenda:

a) dengan seorang wanita yang melahirkan isterinya atau bekas isterinya;

b) dengan seorang wanita bekas isteri orang yang menurunkannya;

c) dengan seorang wanita keturunan isteri atau bekas isterinya, kecuali putusnya hubungan perkawinan dengan bekas isterinya itu qobla al dukhul;

d) dengan seorang wanita bekas isteri keturunannya.

(3) Karena pertalian sesusuan:

a) dengan wanita yang menyusui dan seterusnya menurut garis lurus ke atas;

b) dengan seorang wanita sesusuan dan seterusnya menurut garis lurus ke bawah;

c) dengan seorang wanita saudara sesusuan, dan kemanakan sesusuan ke bawah;

d) dengan seorang wanita bibi sesusuan dan nenek bibi sesusuan ke atas;

e) dengan anak yang disusui oleh isterinya dan keturunannya.

Pasal 40 : Dilarang melangsungkan perkawinan antara seorang pria dengan seorang wanita karena keadaan tertentu:

a) karena wanita yang bersangkutan masih terikat satu perkawinan dengan pria lain;

b) seorang wanita yang masih berada dalam masa iddah dengan pria lain;

c) seorang wanita yang tidak beragama islam.

Pasal 41 : (1) Seorang pria dilarang memadu isterinya dengan seoarang wanita yang mempunyai hubungan pertalian nasab atau sesusuan dengan isterinya;

a) saudara kandung, seayah atau seibu atau keturunannya;

b) wanita dengan bibinya atau kemenakannya. 
(2) Larangan tersebut pada ayat (1) tetap berlaku meskipun isteri-isterinya telah ditalak raj i, tetapi masih dalam masa iddah.

Pasal 42 : Seorang pria dilarang melangsungkan perkawinan dengan seorang wanita apabila pria tersebut sedang mempunyai 4 (empat) orang isteri yang keempat-empatnya masih terikat tali perkawinan atau masih dalam iddah talak raj'i ataupun salah seorang diantara mereka masih terikat tali perkawinan sedang yang lainnya dalam masa iddah talak raj'i.

Pasal 43: (1) Dilarang melangsungkan perkawinan antara seorang pria:

a) dengan seorang wanita bekas isterinya yang ditalak tiga kali;

b) dengan seorang wanita bekas isterinya yang dili`an.

(2) Larangan tersebut pada ayat (1) huruf a. gugur, kalau bekas isteri tadi telah kawin dengan pria lain, kemudian perkawinan tersebut putus ba`da dukhul dan telah habis masa iddahnya.

Pasal 44 : Seorang wanita Islam dilarang melangsungkan perkawinan dengan seorang pria yang tidak beragama Islam

Apabila ada larangan perkawinan yang terdapat antara calon suami dengan calon istri sesuai yang diatur dalam Kompilasi Hukum Islam, maka majelis akan menolak permohonan dispensasi perkawinan bagi pemohon.

d. Pasal 53 Kompilasi Hukum Islam

Dispensasi kawin karena alasan hamil diluar nikah dapat dikabulkan majlis hakim, karena memang majlis hakim berpedoman kepada Kompilasi Hukum islam. Termuat dalam pasal 53 yang menyatakan bahwa:

(1) Seorang wanita hamil di luar nikah, dapat dikawinkan dengan pria yang menghamilinya.

(2) Perkawinan dengan wanita hamil yang disebut pada ayat (1) dapat dialngsungkan tanpa menunggu lebih dahulu kelahiran anaknya.

(3) Dengan dilangsungkannya perkawinan pada saat wanita hamil, tidak diperlukan perkawinan ulang setelah anak yang dikandung lahir

2. Pertimbangan keadilan masyarakat

Fakta persidangan dapat berupa alasan yang diajukan oleh pemohon dispensasi kawin. Untuk menemukan fakta adanya alasan yang sah hakim memilah dan memilih faktor mana yang relevan dan benarbenar menjadi alasan disepensai kawin. Pemilahan dan pemilihan faktor yang relevan dan menjadi fakta dilakukan oleh hakim melalui buktibukti. Dengan kata lain faktor yang diajukan sebagai alasan harus didukung bukti sebagai dasar hakim melakukan konstatir fakta. 
Dalam kehidupan bermasyarakat, pernikahan merupakan salah satu solusi alternatif bagi penyelesaian masalah sosial. Bagi orang tua yang anaknya sudah hamil diluar nikah namun usianya masih dibawah umur pengajuan prermohonan dispensasi nikah merupakan jalan terbaik untuk menutup malu, Hal ini akan menjadi aib bagi keluarga, keluarga akan mendapat hukuman dari lingkungan sosial berupa gunjingan-gunjingan yang tercela. Bagi anaknya sendiri dia akan mendapat hinaan dan cemoohan dari lingkungan sekitar atas apa yang dialaminya, hal tersebut akan berdampak bagi kesehatan mentalnya apalagi usianya masih labil.

Dalam alasan hubungan diluar nikah, hakim selalu mengabulkan permohonan dispensasi nikah. Dengan pertimbangan perempuan yang hamil tanpa suami akan dihina dan dikucilkan oleh masyarakat. Apabila tidak dilakukan pernikahan maka akan berakibat perempuan tersebut tidak mau bergaul dan mementingkan diri sendiri. Hal tersebut juga akan berakibat pada anak yang dikandungnya. Bayi yang tidak berdosa itu harus diberi perlindungan. Perlindungan yang paling berharga, di samping perlindungan-perlindungan lain, adalah perlindungan hukum, yaitu adanya pengakuan secara hukum, bahwa dia lahir ke dunia sebagai anak sah yang mempunyai hak-hak secara penuh baik dari ibu dan ayahnya. Kendati demikian perlindungan hukum bagi anak yang dikandungnya ditentukan oleh keabsahan perkawinan orang tuanya. Akibatnya, tidak hanya mempunyai perlindungan hukum dari orang tuanya juga urusan hukum yang diperlukan akan diwakili oleh orang tuanya baik didalam maupu diluar pengadilan. ${ }^{21}$

Berdasarkan pada penafsiran pada umumnya hakim merumuskan alasan dispensasi antara lain adanya kemudharatan bila tidak dilakukan pernikahan meskipun calon mempelai belum mencapai usia minimum. Karena menurut hukum Islam, menolak kemudharatan harus didahulukan dari pada meraih manfaat. ${ }^{22}$

Majelis melihat calon suami dari pemohon yang akan menjadi suaminya dari segi pekerjaan. Apabila calon suami dari pemohon telah mempunyai pekerjaan atau pengahasilan yang tetap dan dapat memenuhi kebutuhan hidup setelah berumah tangga nantinya, maka majelis dapat mengabulkan permohonan dispensasi perkawinan bagi pemohon.

\section{Analisis Perubahan Usia Minimum Perkawinan Terhadap Permohonan Dispensasi Kawin Di Pengadilan Agama Majalengka}

Undang-Undang Republik Indonesia Nomor 16 Tahun 2019 tentang Perubahan Atas Undang-Undang Nomor 1 Tahun 1974 tentang Perkawinan disahkan Presiden Joko Widodo pada tanggal 14 Oktober 2019 di Jakarta. Undang-undang tersebut mulai berlaku setelah diundangkan Menteri hukum dan hak asasi manusia Tjahjo Kumolo pada tanggal 15 Oktober 2019 di Jakarta. Ditempatkan pada Lembaran Negara Republik Indonesia Tahun

\footnotetext{
${ }^{21}$ Moch. Isnaeni, Op.Cit., hlm118.

${ }^{22}$ Ishaq, Loc, Cit.
} 
PRESUMPTION of LAW Fakultas Hukum Universitas Majalengka

Volume 3 Nomor 2 Oktober 2021

2019 Nomor 186. Penjelasan Atas Undang-Undang Republik Indonesia Nomor 16 Tahun 2019 tentang Perubahan Atas Undang-Undang Nomor 1 Tahun 1974 tentang Perkawinan diundangkan dan ditempatkan dalam Tambahan Lembaran Negara Republik Indonesia Nomor 6401. ${ }^{23}$

Perubahan norma dalam Undang-undang Nomor 1 Tahun 1974 tentang Perkawinan ini menjangkau batas usia untuk melakukan perkawinan, perbaikan norma menjangkau dengan menaikkan batas minimal umur perkawinan bagi wanita. Batas minimal umur perkawinan bagi wanita dipersamakan dengan batas minimal umur perkawinan bagi pria, yaitu 19 (sembilan belas) tahun.

Diharapkan kenaikan batas umur yang lebih tinggi dari 16 (enam belas) tahun bagi wanita untuk kawin memberikan dampak positif bagi kelangsungan hidup bernegara. Dari sisi kemasyarakatan kenaikan tersebut akan mengakibatkan laju kelahiran yang lebih rendah serta mendukung program pemerintah dalam pembatasan pertumbuhan angka kelahiran melalui program Keluarga Berencananya, serta mendukung pula program wajib belajar 12 tahun bagi anak dan diharapkan lebih dari itu akses anak terhadap pendidikan yang setinggi mungkin. Dari sisi Kesehatan pun diharapkan akan menurunkan resiko kematian ibu dan anak. Selain itu juga dapat terpenuhinya hak-hak anak sehingga mengoptimalkan tumbuh kembang anak.

Berdasarkan wawancara yang peneliti lakukan di Pengadilan Agama Majalengka. Menurut narasumber Hakim Pengadilan Agama Majalengka yakni Bapak Dr. Drs. H. Amin Manshur, S.H. M. Hum. menyatakan bahwa penambahan usia minimum untuk melakukan perkawinan merupakan suatu terobosan terbaru dan sangat baik bagi perkembangan ilmu hukum dan berdampak positif bagi masyarakat. Kendati hal tersebut sangat berpengaruh juga kepada tingkat permohonan perkara dispensasi kawin yang diajukan di Pengadilan Agama Majalengka.

Meskipun terjadi perubahan usia hanya bagi pihak perempuan saja jumlah permohonan dispensasi kawin tidak dapat diminimalisir. Karena memang Ketika seseorang menginginkan pernikahnnya meskipun masih dibawah usia minimun tetap bisa melangsungkan pernikahan jika mengantongi dispensasi kawin yang dikeluarkan pengadilan. Hal tersebut mengakibatkan membludaknya permohonan dispensasi kawin di Pengadilan Agama Majalengka.

Dapat dilihat dalam kolom perkembangan perkara yang masuk dari tahun ke tahun terjadi peningkatan berikut ini:

${ }^{23}$ Diakses dari https://www.jogloabang.com/pustaka/uu-16-2019-perubahan-uu-1-1974per kawinan pada tanggal 15 juni 2020. 
PRESUMPTION of LAW

Fakultas Hukum Universitas Majalengka

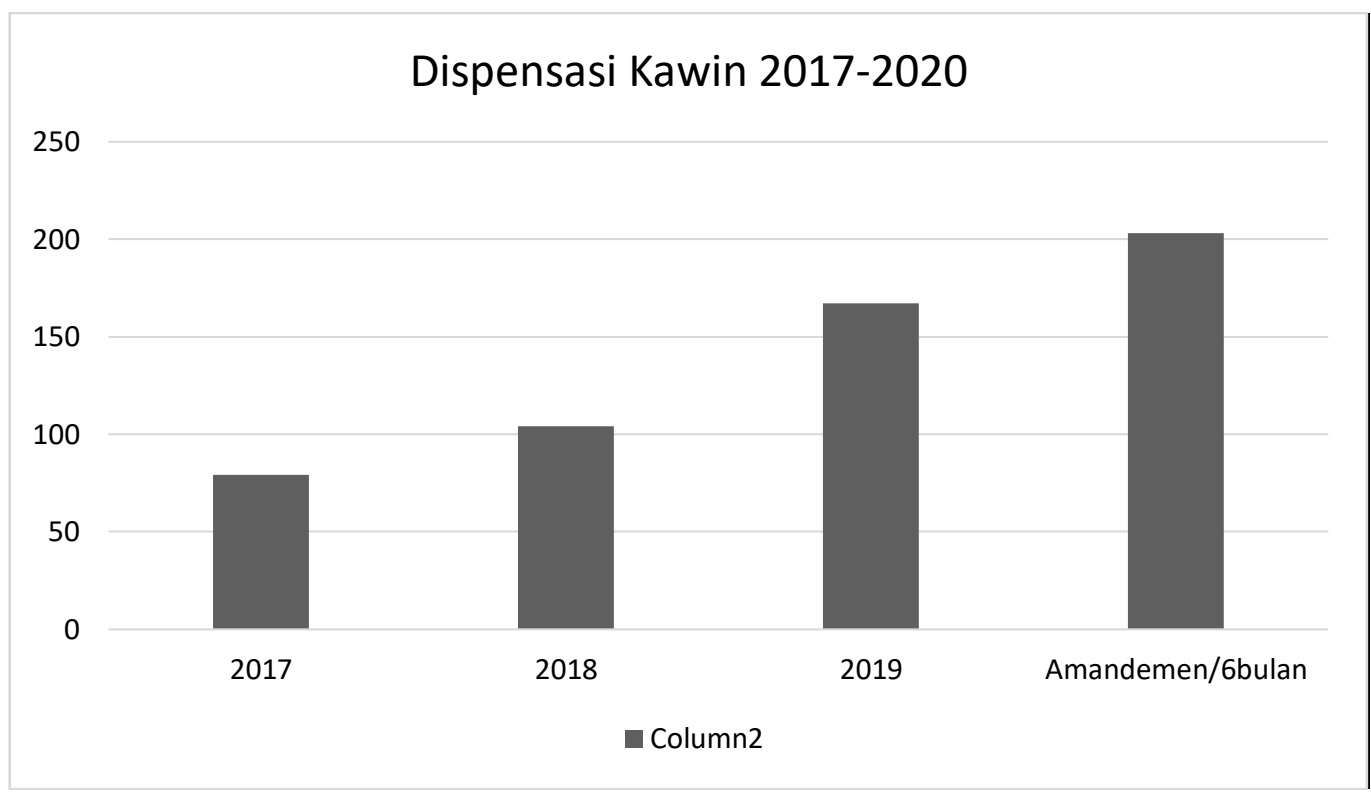

Sampai saat ini tercataan dari mulai penambahan usia perkawinan yang mengajukan dispensasi kawin mulai terlihat terjadi kenaikan. Tercataan mulai bulan oktober 2019-maret 2020 sudah 203 perkara yang masuk. Hal tersebut berarti sudah terjadi kenaikan yang signifikan dibandingkan dengan undang-undang yang terdahulu ada sekitar $100 \%$ kenaikan terutama para pemohon dari pihak perempuan.

Hal tersebut dikarenakan tidak sejalannya antara kenaikan usia pernikahan dengan faktor yang diajukan para pemohon. Yang mana dengan ditaikannya umur minimum tersebut tidak ada kaitannya dengan faktor pengajuan dispensasi kawin. Karena memang jumlah faktor permohonan terbanyak yang diajukan adalah karena faktor hamil diluar kawin dan juga para orang tua menghawatirkan anaknya terjerumus kepada hal yang dilarang oleh agama.

\section{G. KESIMPULAN}

1. Faktor-faktor yang melatarbelakangi orang tua mengajukan permohonan dispensasi kawin di Pengadilan Agama Majalengka adalah faktor pencegahan, pengobatan dan ekonomi lemah. Faktor pencegahan, dimaksudkan para orang tua karena khawatir melihat anaknya berhubungan sudah sangat lama dan begitu dekat, hal tersebut mengakibatkan orang tua khawatir jika anaknya melakukan hal yang dilarang oleh agama. Faktor pengobatan, dimaksudkan karena kedekatan pasangan muda mudi yang sangat begitu dekat dan tanpa adanya batasan sehingga mengakibatkan perbuatan yang dilarang oleh agama yang berujung kepada hamil diluar nikah, karenanya pihak keluarga dan juga anaknya menjadi bahan gunjingan dan dikucilkan karena memang hamil tanpa ayah, dan pula ditakutkan Ketika anaknya sudah lahir anak tersebut tidak memiliki kedudukan dimata hukum. Hal tersebut menjadikan alasan hamil diluar nikah menjadi alasan terbanyak yang diajukan para pemohon untuk dikabulkan. Kendala ekonomi 
PRESUMPTION of LAW

Fakultas Hukum Universitas Majalengka

Volume 3 Nomor 2 Oktober 2021

yang kurang juga menjadi faktor pendukung perkara dispensasi kawin. Para orangtua menganggap bahwa dengan menikahkan anaknya maka beban perekonomian keluarga akan sedikit berkurang.

2. Dasar yang digunakan hakim Pengadilan dalam menetapkan dispensasi nikah adalah pasal 7 ayat 2 Undang-undang Perkawinan, Peraturan Mahkamah Agung Nomor 5 Tahun 2019 dan Kompilasi Hukum Islam. Sedangkan yang menjadi dasar keadilan pertimbangan hakim adalah demi tercapainya kemaslahatan dan mengurangi kemahdaratan yang melihat kepada keadilan kesejahteraan masyarakat. Dalam pemeriksaannya hakim melihat kesiapan fisik dan psikis pemohon serta penghasilan yang dimiliki calon mempelai pria untuk kehidupan keluarganya kedepan. Dasar hakim menolak permohonan dispensasi nikah kesiapan calon belum matang dari segi fisik, mental dan ekonomi, hubungan tidak begitu mengkhawatirkan untuk segera dinikahkan.

3. Amandemen UU Perkawinan menyebabkan kenaikan batas usia perkawinan. Dan hal ini menjadi salah satu penyebab terjadinya lonjakan Permohonan Dispensasi Kawin yang diajukan di Pengadilan Agama Majalengka. Dalam periode 6 bulan saja setelah terjadi kenaikan usia perkawinan jumlah Permohonan Dispensasi Kawin yang diajukan sudah mencapai dua kali lipat kenaikan. Hal tersebut mengakibatkan terjadinya penumpukan perkara di Pengadilan Agama Majalengka. Dari hal tersebut dapat disimpulkan bahwa Amandemen UU Perkawinan dianggap tidak efektif didalam menekan angka dispensasi kawin.

\section{H.SARAN}

1. Para orang tua hendaknya memperkenalkan ajaran agama sejak dini dan tanpa putus kepada anak-anaknya, sehingga akan menjauhkan anak tersebut dari perbuatan yang kurang baik khususnya yang dilarang oleh agama. Memberikan kesempatan kepada anak-anaknya untuk memperoleh Pendidikan yang baik serta mengupayakan agar meraih Pendidikan standar minimal 12 tahun. Pengawasan para orang tua terhadap anaknyapun harus diperketat, terlebih Ketika anak tersebut sudah mempunyai pasangan namun belum terjadi pernikahan.

2. Dalam persidangan dispensasi kawin, hakim diharapkan lebih selektif lagi. Mengingat akibat dari perkawinan dibawah umur sangat menghawatirkan. Kecuali kalau memang alasan karena faktor kuratif (penyembuhan) yang sangat mendesak.

3. Kenaikan usia perkawinan sebaiknya diuji lagi kelayakannya, karena memang hal tersebut berakibat kepada kelonjakan permohonan dispensasi kawin yang terjadi di Pengadilan Agama Majalengka sangat tinggi. 


\section{DAFTAR PUSTAKA}

\section{A. Buku}

Bayu Wasono, Dispensasi Nikah (Akibat Hamil Diluar Nikah), Guepedia, 2020.

Beni Ahmad Saebani,Fiqh Munakahat 1, Pustaka Setia, Bandung, 2018.

Charlie Rudyat, Kamus Hukum, Pustaka Mahardika.

Fakultas Hukum Universitas Majalengka, Panduan Skripsi, Fakultas Hukum Universitas Majalengka, Majalengka, 2019.

Ishaq, Pengantar Hukum Indonesia (PHI), Rajawali Pers, Jakarta, 2016.

Mardani, Hukum Keluarga Islam di Indonesia, Edisi Pertama, Prenadamedia Group, Jakarta, 2016.

Moch. Isnaeni, Hukum Perkawinan Indonesia, Refika Aditama, Bandung, 2016.

Roihan A Rasyid, Hukum Acara Peradilan Agama, Raja Grafindo Persada, Jakarta, 1998.

Sudarsono, Hukum Perkawinan Nasional, Rineka Cipta, Jakarta, 2010.

\section{B. Undang-Undang}

Undang-Undang Dasar Negara Republik Indonesia Tahun 1945.

Undang-undang Nomor 23 Tahun 2002 Tentang Perlindungan Anak.

Undang -undang Nomor 16 Tahun 2019 tentang Atas Perubahan Undangundang Nomor 1 Tahun 1974 Tentang Perkawinan.

Undang-undang Nomor 1 Tahun 1974 Tentang Perkawinan.

Undang- undang Nomor 3 Tahun 2006 tentang Peradilan Agama.

Undang-undang Nomor 12 Tahun 2011 tentang Pembentukan Peraturan Perundang-Undangan.

Kompilasi Hukum Islam. 
Penjelasan Atas Undang-Undang Republik Indonesia Nomor 23 Tahun 2002 Tentang Perlindungan Anak.

Peraturan Mahkamah Agung Nomor 5 tahun 2019 tentang Pedoman Mengadili Permohonan Dispensasi Kawin.

\section{Sumber Lainnya}

https://id.wikipedia.org.

https://www.jogloabang.com.

https://id.m.wikipedia.org.

https://www.kanal info.web.id.

https://www.hukumonline.com.

https://pa-purwodadi.go.id.

https://web.pa-majalengka.go.id .

https://badilag.mahkamahagung.go.id.

http://digilib.unila.ac.id/528/ 8/BAB\%203.pdf.

http://repo.iain-tulungagung.ac.id/10133/5/BAB\%20II.pdf.

http://repository. unpas.ac.id/41852/4/F.\%20BAB \%201.pdf.

Bab II hlm. 34, http://repository.unpas.ac.id/33652/1 /0 7\% 20BAB \%20II.pdf. Salinan Putusan Mahkamah Konsititusi Nomor: 22/PUU-XV/2017 Tentang Batas Usia Minimal Perkawinan, hlm 48. Diakses dari https://mkri.id/public /content/persidangan/putusan/22_PUUXV_2017.pdf.

Jalaluddin, Hakikat Dan Fungsi Peraturan Perundang-Undangan Sebagai Batu Uji Kritis Terhadap Gagasan Pembentukan Perda Yang Baik.

Sabariah, Perkembangan Fisik Remaja, jurnal.

Sri Rahmawaty Yunus dan Ahmad Faisal, "Analisis Penetapan Dispensasi Kawin Dalam Perspektif Undang-Undang Perlindungan Anak (Studi Kasus Di Pengadilan Agama Limboto” Jurnal Ilmiah Al-Jauhari (JIAJ), 2 September 2018. 
Refqi Alfina, Zainul Akhyar, dan Harpani Matnuh, Implikasi Psikologis Pernikahan Usia Dini Studi Kasus Di Kelurahan Karang Taruna Kecamatan Pelaihari Kabupaten Tanah Laut, Jurnal Pendidikan Kewarganegaraan, 2016.

M. Sulaeman Jajuli, Kepastian Hukum Gadai Tanah Dalam Islam, CV. Budi Utama, Yogyakarta, 2015.

Achmad Ali, Menguak Tabir Hukum (Suatu Kajian Filosofis dan Sosiologis) Toko Gunung Agung, Jakarta, 2002, hlm.82-83. Lihat Bab II hlm. 17. http://repository.uma.ac.id/bitstream/123456789/1435/5/138400056_File 5.pdf.

Ilham, Penyelesaian Perkara Isbat Nikah Di Pengadilan Agama Watampone Kelas I, Skripsi Fakultas Syar'iah Dan Hukum Uin Alauddin Makassar, 2017.

Nurwafa Ramadanti, Aspek-Aspek Hukum Terhadap Dampak Perkawinan Yang Tidak Tercatat Dalam Perspektif Hukum Positif Dan Hukum Islam, Skripsi Fakultas Hukum Universitas Majalengka, 2020.

Ummu Kalsum, Pengaruh Dispensasi Nikah Terhadap Tingkat Perceraian Di Pengadilan Agama Watampone Kelas IA, Skripsi.

Administrasi Perkara Pengadilan Agama Majalengka.

Buku Register Panitera Pengadilan Agama Majalengka Kelas IA. 